\title{
Development of classification criteria for resistance to soybean rust and differences in virulence among Japanese and Brazilian rust populations
}

\author{
Naoki Yamanaka ${ }^{1}$, Yuichi Yamaoka ${ }^{2}$, Masayasu Kato ${ }^{1 *}$, Noelle G. Lemos ${ }^{1}$, André L. de L. Passianotto ${ }^{3}$, João \\ V.M. dos Santos ${ }^{3}$, Eduardo R. Benitez ${ }^{4}$, Ricardo V. Abdelnoor ${ }^{3}$, Rafael M. Soares ${ }^{3}$ \& Kazuhiro Suenaga ${ }^{1}$ \\ ${ }^{1}$ Japan International Research Center for Agricultural Sciences - JIRCAS, 1-1, Ohwashi, Tsukuba, Ibaraki, 305-8686, Japan; \\ ${ }^{2}$ Graduate School of Life and Environmental Sciences, University of Tsukuba, 1-1-1 Tennodai, Tsukuba, Ibaraki, 305-8572, \\ Japan; ${ }^{3}$ Embrapa Soja, 86001-970, Londrina PR, Brazil; ${ }^{4}$ National Institute of Crop Science - NICS, 2-1-18 Kannondai, \\ Tsukuba, Ibaraki, 305-8518, Japan
}

Author for correspondence: N. Yamanaka, e-mail: naokiy@affrc.go.jp

\begin{abstract}
In recent years soybean rust, caused by Phakopsora pachyrhizi has become one of the most serious threats to soybean production in Brazil. Breeding lines and varieties have been selected for resistance to soybean rust in Asia. However, differences in virulence between Asian and Brazilian rust populations should be considered in order to select and use resistant resources from Asia. Here, we suggest criteria for distinguishing resistant from susceptible types by the analysis of four resistance characters: frequency of lesions having uredinia, number of uredinia per lesion, frequency of open uredinia, and sporulation level, determined by the utilization of 63 genotypes. Under growth chamber conditions, a set of 13 soybean varieties were exposed to three rust populations - one from Japan and two from Braziland evaluated for the resistance characters mentioned above. The Japanese and Brazilian populations clearly differed in virulence, as did the two Brazilian populations. Only two resistance genes, Rpp 4 from PI459025 and Rpp 5 from Shiranui, commonly conferred resistance on all three rust populations. The number of resistant varieties or resistance genes useful in both countries appears limited. Therefore, a resistant cultivar that is universally effective against soybean rust should be developed by pyramiding some major resistance genes and by introducing horizontal resistance.
\end{abstract}

Keywords: Phakopsora pachyrhizi, lesion type, pathogenicity, resistant variety

\section{RESUMO}

Desenvolvimento de critério de classificação da resistência à ferrugem asiática da soja e diferenças de virulência entre populações do Japão e do Brasil

Nos últimos anos a ferrugem asiática, causada pelo fungo Phakopsora pachyrhizi tornou-se uma das mais sérias ameaças a produção de soja Brasileira. Linhagens melhoradas e variedades têm sido selecionadas para a resistência à ferrugem da soja na Ásia, entretanto para a seleção e utilização dessas fontes de resistência, diferenças de virulência entre populações Asiáticas e Brasileiras desse fungo devem ser consideradas. Neste trabalho sugerimos um critério para se distinguir resistência de susceptibilidade pela análise de quatro caracteres de resistência: freqüência de lesões contendo urédias, número de urédias por lesão, freqüência de urédias abertas e nível de esporulação determinados pela utilização de 63 genótipos. Sob condições controladas em câmaras de crescimento, treze variedades de soja foram expostas a três populações de fungos - uma população proveniente do Japão e duas populações provenientes do Brasil-e avaliadas quanto aos caracteres de resistência mencionados acima. As populações Brasileiras diferiram entre si claramente quanto a virulência e em relação à população de isolados do Japão. Apenas dois genes de resistência, Rpp 4 presente na variedade PI459025 e Rpp5 presente na variedade Shiranui conferiram resistência as três populações da ferrugem. O número de variedades ou genes resistentes úteis em ambos os países parece ser limitado. Assim, um cultivar universalmente efetivo contra a ferrugem da soja deveria ser desenvolvido pela piramidação de genes maiores de resistência e pela introdução de resistência horizontal.

Palavras-chave: Phakopsora pachyrhizi, tipo de lesão, patogenicidade, variedade resistente.

\section{INTRODUCTION}

Soybean rust, caused by Phakopsora pachyrhizi Syd. \& P. Syd., has been observed in Japan for more than 100

*Present address: National Agricultural Research Center - NARC, 3-11 Kannondai, Tsukuba, Ibaraki, 305-8666, Japan years (Hennings, 1903); it has also been detected in many Asian countries and reached South American countries such as Brazil, Paraguay, Argentina, Bolivia and Colombia in recent years (Rossi, 2003; Yorinori et al., 2005). Since 2001, when soybean rust was discovered in Brazil, it has become one of the most serious threats to soybean (Glycine max (L.) Merr.) production in this country because it can potentially 
reduce the soybean yield by more than $75 \%$ (Navarro et al., 2004; Ivancovich, 2005; Yorinori et al., 2005).

The development of resistant varieties is an efficient way to manage soybean rust. Five major resistance genesRpp1, Rpp2, Rpp3, Rpp4, and Rpp5- have been identified in Asian soybean varieties (Hartwig \& Bromfield, 1983; Hartwig, 1986; Garcia et al., 2008; Pierozzi et al., 2008). Most of the major resistance genes are considered race-specific (Bromfield \& Hartwig, 1980, 1983; Bromfield, 1984; Hartwig, 1986) and the pathogen of soybean rust presents high race variability (Yamaoka et al., 2002; Oliveira et al., 2005). Thus, although many breeding lines and cultivars have been selected for resistance to soybean rust in Asia, they cannot be utilized without knowledge of the differences in virulence between South American and Asian rust populations. In order to use these resistant materials from Asia in the Brazilian breeding program, we need to determine the differences in virulence between Asian and South American rust populations by using a single, comprehensive method of virulence evaluation.

The "lesion type" classification, based on lesion color and the number of sporulating uredinia, has been used to identify the virulence of soybean rust isolates (Bromfield, 1984). However, lesion color can vary a lot and some resistant lesions that do not sporulate can be found in tan-colored lesions. In addition, continuous variation of lesion color among varieties makes it difficult to group all phenotypes into a limited number of lesion types, such as RB (Resistant) and TAN (Susceptible) (Kato \& Yorinori, 2008). On the other hand, lesion color is known to be controlled by resistance genes. For example, quantitative trait locus (QTL) analysis of lesion color in $120 \mathrm{~F}_{2}$ plants revealed that major resistance genes, Rpp2 from PI230970 and Rpp4 from PI459025, can genetically contribute to the darkening of lesion color under greenhouse conditions (Yamanaka et al., 2008). Thus, lesion color should also be considered when selecting resistant genotypes. Bonde et al. (2006) suggested that the number and size of uredinia are desirable indexes for detecting resistance derived from major genes and also partial resistance to soybean rust. These indexes are represented by numerical values and are considered more suitable than the index based on lesion color for deciding resistance because of their objectivity.

To choose appropriate traits that would enable us to classify levels of soybean rust resistance in soybean cultivars, we investigated five traits related to resistance in 63 genotypes infected with a Japanese rust population. We also investigated the application of these traits to the determination of differences in virulence among three rust populations collected in Japan and Brazil during 2007 and 2008.

\section{MATERIALS AND METHODS}

\section{Japanese and Brazilian rust populations}

In this study, we used non-purified isolates derived from single spore isolation and rust populations putatively containing various races. This choice was because our objective was to clarify the regional differences in virulence of soybean rust by comparing dominant races in each region, rather than some specific races. The Japanese rust population (JRP) was collected from rust-infected soybean in an experimental field of the National Agricultural Research Center (NARO), Tsukuba, Ibaraki, Japan in September 2007. Infected leaflets were collected in plastic bags. Urediniospores on more than 20 leaflets were mixed and put into microtubes. Open microtubes containing urediniospores were placed on silica gel for 1 day and then stored at $-80{ }^{\circ} \mathrm{C}$. Urediniospores of JRP were propagated on Glycine max cv. Tachinagaha before they were used for inoculation. Brazilian rust population 1 (BRP-1) was obtained from a greenhouse at the Brazilian Agricultural Research Corporation, National Soybean Research Center (Embrapa Soja), Londrina PR, Brazil in January 2008. BRP-1 was originally derived from a commercial field in the state of Mato Grosso and had been maintained on Glycine max cv. BRSMS Bacuri in the greenhouse. BRP-1 has been used in previous studies (Yamanaka et al., 2007b; Kato \& Yorinori, 2008; Silva et al., 2008; Yamanaka et al., 2008). Brazilian rust population 2 (BRP-2) was also obtained from a greenhouse at Embrapa Soja in August 2008. BRP-2 had the same origin as BRP-1 but had been maintained on various soybean genotypes in a different greenhouse at EMBRAPA Soja. BRP-2 was imported to Japan (Import permit No. 20Y157) and used for the experiments, together with JRP, at the Japan International Research Center for Agricultural Sciences (JIRCAS). The experiment using BRP-1 was performed at EMBRAPA Soja. All experiments were carried out according to the conditions described below. Urediniospores of each rust population were suspended in distilled water with $0.04 \%$ (v/v) of polyoxyethylene sorbitan monolaurate (Tween 20, Sigma) to prepare suspensions of about 50,000 spores $/ \mathrm{mL}$ for inoculation.

\section{Plant materials and growth conditions}

Sixty-three soybean genotypes (cultivars/lines), including materials previously reported as having resistance to soybean rust (Table 1), were evaluated for resistance to the JRP. Thirteen varieties (entries 1 to 13 in Table 1), derived and multiplied from a single seed from the Embrapa Soja gene bank, were used to identify virulence differences among the 3 rust populations. Nine soybean cultivars (entries 1 to 9) were known to have major resistance genes and were therefore considered to be resistance standards. Two cultivars, TK5 and Wayne (entries 12 and 13) were used as susceptible materials. The other two PI lines (entries 10 and 11) previously reported as resistant to a mixture of isolates from four regions (Miles et al., 2006), were also included as resistant materials in a set of standard variety. Sixty-three soybean genotypes for infection from JRP were divided into a total of five experimental sets consisting of 12 or 13 genotypes. Each single experiment using thirteen varieties was performed for infection from BRP-1 and 
Development of classification criteria for resistance to soybean rust and differences...

TABLE 1 - Soybean genotypes used in this study. All 63 were used initially to test the Japanese rust population, and entries 1 to 13 were also used to test the Brazilian rust populations

\begin{tabular}{|c|c|c|c|c|}
\hline \multicolumn{2}{|c|}{ EntryGenotype } & \multirow{2}{*}{$\frac{\text { Characteristics }}{\text { Standard variety (SV) having Rppl }}$} & \multirow{2}{*}{$\frac{\text { Source }^{4}}{\text { EMBRAPA }}$} & \multirow{2}{*}{$\frac{\text { Reference }}{\text { Hartwing and Bromfield, } 1983}$} \\
\hline 1 & PI200492(Komata) & & & \\
\hline 2 & Tainung 4 & SV having Rppl & EMBRAPA & Yamaoka et al., 2002 \\
\hline 3 & PI587880A(Huang Dou) & SV having Rppl & EMBRAPA & Ray et al., 2009 \\
\hline 4 & PI587886(Bai Dou) & SV having Rppl & EMBRAPA & Ray et al., 2009 \\
\hline 5 & PI230970(No.3) & SV having $R p p 2$ & EMBRAPA & Hartwing and Bromfield, 1983 \\
\hline 6 & PI417125 (Kyushu 31) & SV having $R p p 2^{1}$ & EMBRAPA & Nogueira et al., 2008 \\
\hline 7 & PI462312 (Ankur) & SV having $R p p 3$ & EMBRAPA & Hartwing and Bromfield, 1983 \\
\hline 8 & PI459025 (Bing Nan) & SV having $R p p 4$ & EMBRAPA & Hartwing, 1986 \\
\hline 9 & Shiranui & SV having $R p p 5^{2}$ & EMBRAPA & Garcia et al., 2008 \\
\hline 10 & PI416764(Akasaya) & SV & EMBRAPA & Arias et al., 2008 \\
\hline 11 & PI587905 (Xiao Huang Dou) & SV & EMBRAPA & Miles et al., 2006 \\
\hline 12 & TK5 & SV of susceptible control & EMBRAPA & Yamaoka et al., 2002 \\
\hline 13 & Wayne & SV of susceptible control & EMBRAPA & Yamaoka et al., 2002 \\
\hline 14 & PI459025A & Resistant variety putatively having $R p p 4$ & EMBRAPA & Pierozzi et al., 2008 \\
\hline 15 & PI594767A & Resistant variety & EMBRAPA & Miles et al., 2006 \\
\hline 16 & GC00002-100 & Resistant variety developed by AVRDC & AVRDC & AVRDC, 1989 \\
\hline 17 & GC00138-29 & Resistant variety developed by AVRDC & AVRDC & AVRDC, 1989 \\
\hline 18 & GC60020-8-7-7-18 & Resistant variety developed by AVRDC & AVRDC & AVRDC, 1989 \\
\hline 19 & GC84040-16-1 & Resistant variety developed by AVRDC & AVRDC & AVRDC, 1992 \\
\hline 20 & GC84051-9-1 & Resistant variety developed by AVRDC & AVRDC & AVRDC, 1992 \\
\hline 21 & GC84058-21-4 & Resistant variety developed by AVRDC & AVRDC & AVRDC, 1992 \\
\hline 22 & GC85037-2-3-5-1 & Resistant variety developed by AVRDC & AVRDC & Yorinori, 2008 \\
\hline 23 & GC85039-1-2-1-1 & Resistant variety developed by AVRDC & AVRDC & - \\
\hline 24 & GC860049 & Resistant variety developed by AVRDC & AVRDC & AVRDC, 1992 \\
\hline 25 & SS86045-23-2 & Resistant variety developed by AVRDC & AVRDC & AVRDC, 1992 \\
\hline 26 & GC87012-10-B-5 & Resistant variety developed by AVRDC & AVRDC & AVRDC, 1992 \\
\hline 27 & GC87016-11-B-2 & Resistant variety developed by AVRDC & AVRDC & AVRDC, 1992 \\
\hline 28 & SRE-B-15C & Resistant variety developed by AVRDC & AVRDC & AVRDC, 1989 \\
\hline 29 & SRE-D-11C & Resistant variety developed by AVRDC & AVRDC & Oloka et al., 2008 \\
\hline 30 & Xiao Jing Huang & Resistant variety screened from genetic resources & JAAS & Yamanaka et al., 2007a, 2008 \\
\hline 31 & Niu Mao Huang & Resistant variety screened from genetic resources & JAAS & Yamanaka et al., 2007a, 2008 \\
\hline 32 & Qin Dou & Resistant variety screened from genetic resources & JAAS & Yamanaka et al., 2007a, 2008 \\
\hline 33 & Da Bai Qi & Resistant variety screened from genetic resources & JAAS & Yamanaka et al., 2007a, 2008 \\
\hline 34 & 6611 & Resistant variety screened from genetic resources & JAAS & Yamanaka et al., 2007a, 2008 \\
\hline 35 & Himedaizu & Resistant variety screened from genetic resources & JIRCAS & Yamanaka et al.,2007a, 2008 \\
\hline 36 & Lu Pi Dou & Resistant variety screened from genetic resources & JAAS & Yamanaka et al., 2007a, 2008 \\
\hline 37 & Hei Dou & Resistant variety screened from genetic resources & JAAS & Yamanaka et al., 2007a, 2008 \\
\hline 38 & $\mathrm{Da} \mathrm{Li} \mathrm{Zi}$ & Resistant variety screened from genetic resources & JAAS & Yamanaka et al., 2007a, 2008 \\
\hline 39 & Hougyoku & Resistant variety & NICS & - \\
\hline 40 & Sachiyutaka & Resistant variety & NICS & - \\
\hline 41 & FT2 & Resistant variety putatively having $R p p 3^{3}$ & EMBRAPA & Yamanaka et al., 2007b \\
\hline 42 & Davis & Susceptible variety & EMBRAPA & Yamanaka et al., 2007b \\
\hline 43 & Kinoshita & Resistant variety having $R p p 5^{4}$ & EMBRAPA & Garcia et al., 2008 \\
\hline 44 & Abura & Resistant variety & EMBRAPA & Laperuta et al., 2008 \\
\hline 45 & RI75 & Susceptible variety & EMBRAPA & - \\
\hline 46 & BR01-17996 & Breeding line resistant to soybean rust & EMBRAPA & - \\
\hline 47 & BR01-18437 & Resistant line having single recessive major gene & EMBRAPA & Pierozzi et al., 2008 \\
\hline 48 & BRSMS-Bacri & Resistant variety putatively having $R p p 3^{3}$ & EMBRAPA & Kato and Yorinori, 2008 \\
\hline 49 & EMBRAPA48 & Susceptible variety & EMBRAPA & Ribeiro et al., 2008 \\
\hline 50 & Misuzudaizu & Susceptible variety & Chiba Univ. & Yamanaka et al., 2001 \\
\hline 51 & Moshidou Gong 503 & Susceptible variety & Chiba Univ. & Yamanaka et al., 2001 \\
\hline 52 & BRS184 & Susceptible variety & EMBRAPA & Yamanaka et al., 2008 \\
\hline 53 & BRS231 & Tolerant variety & EMBRAPA & Yamanaka et al., 2008 \\
\hline 54 & $\mathrm{BB} 17$ & Recombinant Inbred Line from BRS184 X BRS231 & EMBRAPA & Yamanaka et al., 2008 \\
\hline 55 & BB18 & Recombinant Inbred Line from BRS184 X BRS231 & EMBRAPA & Yamanaka et al., 2008 \\
\hline 56 & BB19 & Recombinant Inbred Line from BRS184 X BRS231 & EMBRAPA & Yamanaka et al., 2008 \\
\hline 57 & $\mathrm{BB} 20$ & Recombinant Inbred Line from BRS184 X BRS231 & EMBRAPA & Yamanaka et al., 2008 \\
\hline 58 & $\mathrm{BB} 21$ & Recombinant Inbred Line from BRS184 X BRS231 & EMBRAPA & Yamanaka et al., 2008 \\
\hline 59 & $\mathrm{BB} 22$ & Recombinant Inbred Line from BRS184 X BRS231 & EMBRAPA & Yamanaka et al., 2008 \\
\hline 60 & $\mathrm{BB} 25$ & Recombinant Inbred Line from BRS184 X BRS231 & EMBRAPA & Yamanaka et al., 2008 \\
\hline 61 & BB26 & Recombinant Inbred Line from BRS 184 X BRS231 & EMBRAPA & Yamanaka et al., 2008 \\
\hline 62 & $\mathrm{BB} 28$ & Recombinant Inbred Line from BRS184 X BRS231 & EMBRAPA & Yamanaka et al., 2008 \\
\hline 63 & $\mathrm{BB} 29$ & Recombinant Inbred Line from BRS184 X BRS231 & EMBRAPA & Yamanaka et al., 2008 \\
\hline
\end{tabular}

${ }^{1}$ PI417125 has been confirmed to have Rpp2 by allelism testing with PI230970 (Nogueira et al. 2008); ${ }^{2}$ Kinoshita and Shiranui have a single resistance gene, which is mapped as Rpp 5 (Garcia et al. 2008); ${ }^{3} \mathrm{FT} 2$ and BRSMS-Bacri putatively have the same resistance gene, Rpp3, located in linkage group C2 (Monteros et al. 2006; Arias et al. 2008); ${ }^{4}$ EMBRAPA: Brazilian Agricultural Research Corporation, AVRDC: Asian Vegetable Research and Development Center, JAAS: Jilin Academy of Agricultural Sciences, JIRCAS: Japan International Research center for Agricultural Sciences, NICS: National Institute of Crop Science. 
BRP-2, respectively. All sets of experiments were carried out using the following growth conditions.

Three plants per genotype were grown in pots filled with soil from the field, in a growth chamber at $24^{\circ} \mathrm{C}$ and under a $14-\mathrm{h}$ light photoperiod. Luminance at the soil surface of the chamber was 19,000 to 23,000 lux, provided by fluorescent lamps. Plants were inoculated with spore suspension when they had reached the V3 to V4 growth stage (Fehr et al., 1971). The lower surface of first trifoliolate leaves was scrubbed by the fingers with distilled water for about 10 seconds per leaflet in order to receive the spore suspension well, and then the spore suspension (about $0.1 \mathrm{~mL}$ per one leaf) was spread homogenously on the lower surface of the leaves with a paintbrush. Inoculated plants were covered with plastic bags to maintain humidity and the temperature was kept at $24^{\circ} \mathrm{C}$ for $24 \mathrm{~h}$. Then the plastic bags were removed and the inoculated plants were transferred into the growth chamber under the same temperature and luminance conditions as described above for another 13 days until evaluation. Each experiment respectively for the infections from JRP, BRP-1, and BRP-12 was performed in the present study.

\section{Evaluation}

Lesion color (LC) and number of uredinia per lesion (NoU), which have been used to determine resistance to soybean rust (Bromfield 1984.), were scored two weeks after inoculation. In addition, frequency of lesions that had uredinia $(\% \mathrm{LU})$, frequency of open uredinia $(\% \mathrm{OU})$, and sporulation level (SL) were also evaluated. Thus a total of five resistance characters were evaluated under a stereomicroscope. LC of each lesion was classified into six categories in accordance with the method of Kato \& Yorinori (2008): 1 (very dark) to 6 (very light). SL of each lesion was classified into 0 (no spores) to 3 (abundant spores) (Figure
1). Phenotypic data for $\% \mathrm{LU}$ and $\% \mathrm{OU}$ were obtained from at least 30 lesions per genotype and phenotypic data for LC, NoU and SL were decided by the average values of at least 30 lesions from three plants. Pearson's correlations between these five characters and their significance were also calculated.

Phenotypic values in these resistance characters were respectively classified into resistant or susceptible types. Then five resistance categories of soybean genotypes: Immunity, Highly resistant, Resistant, Slightly resistant, or Susceptible, were determined based on the types in the resistance characters. We judged the differences in virulence among rust populations by these five categories of resistance in soybean genotypes.

\section{RESULTS}

\section{Phenotypes of resistance against JRP}

Phenotypic values of the five resistance characters in the 63 soybean genotypes, which had been infected with JRP, were arranged on the basis of their SLs (Table 2). Then frequency distributions of the five resistance characters in the 63 genotypes (Figure 2) were created. All the frequency distributions except that for LC were bimodal, and the genotypes could mostly be clearly classified into two classes: resistant and susceptible, although some showed intermediate values. On the other hand, continuous variation in LC was observed. In addition, in three genotypes, SRE-D-11C, PI587905, and Shiranui showed imperfect formation of lesions that might have been caused by very strong resistance (e.g. SRE-D-11C in Figure 3). Therefore, various types of lesions in terms of LC and SL were also observed (Figure 3).

All correlations among the five characters were significant at the level of $P<0.001$ by t-test. Correlations among the four characters excluding LC were very high, with values of 0.868 to 0.953 ; LC had lower correlations

A
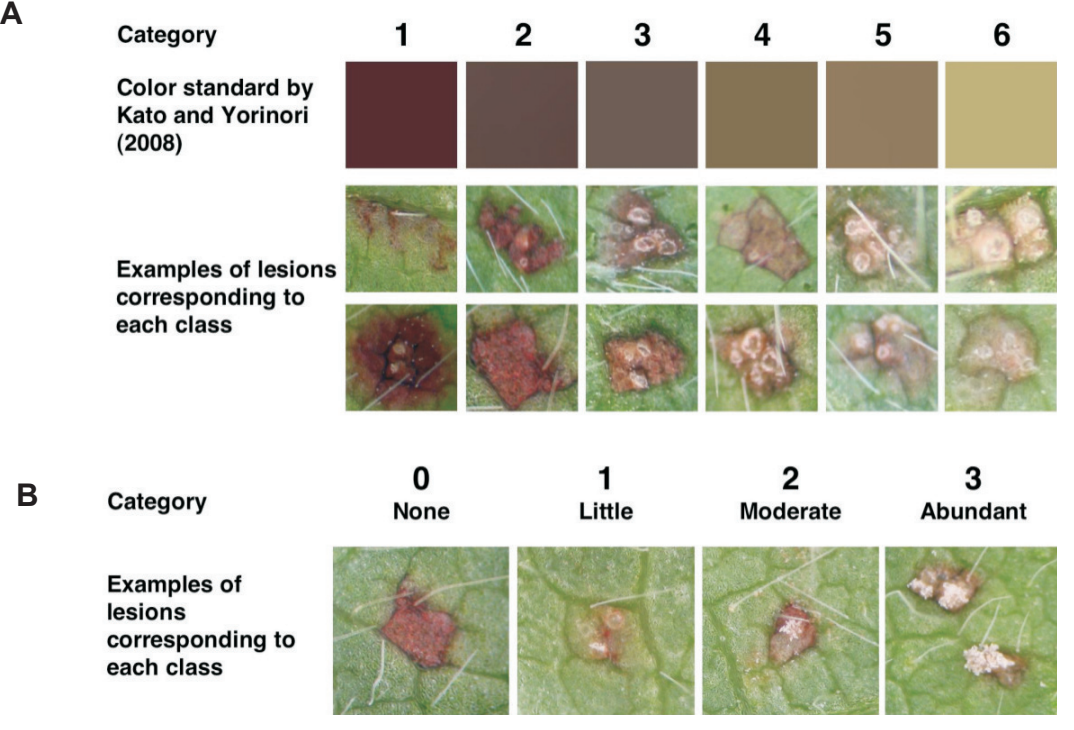

FIGURE 1 - Standards for lesion color A. and sporulation level B. Pictures of lesions for the color standard were taken after removal of the urediniospores to clearly reveal the color. Imperfect formation of lesions might have been the result of a hypersensitive response; lesions with this type of pigmentation were classified into lesion color class 1 . 
Development of classification criteria for resistance to soybean rust and differences...

TABLE 2 - Phenotypes of the five resistance characters against the Japanese rust population in 63 soybean genotypes. List arrangement is determined by the values of the 5 resistance characters in the following order: first: sporulation level (SL); second: number of uredinia $(\mathrm{NoU})$; third: frequency of lesions with uredinia $(\% \mathrm{LU})$; fourth: frequency of open uredinia $(\% \mathrm{OU})$; fifth: lesion color (LC). All values are rounded off to the first decimal place

\begin{tabular}{|c|c|c|c|c|c|c|c|}
\hline \multicolumn{2}{|c|}{ EntryGenotype } & \multirow{2}{*}{ LC } & \multirow{2}{*}{$\% \mathbf{L U}^{1}$} & \multirow{2}{*}{$\mathrm{NoU}^{2}$} & \multirow{2}{*}{$\% \mathrm{OU}^{3}$} & \multirow{2}{*}{$\mathrm{SL}^{4}$} & \multirow{3}{*}{$\begin{array}{l}\text { Resistance classification }^{\mathbf{5}} \\
\text { Immune } \\
\text { Highlv resistant (almost immune) }\end{array}$} \\
\hline 3 & PI587880A & & & & & & \\
\hline 29 & SRE-D-11C & 1.0 & $0.0 \%$ & 0.0 & $0.0 \%$ & 0.0 & \\
\hline 11 & PI587905 & 2.3 & $0.0 \%$ & 0.0 & $0.0 \%$ & 0.0 & Highly resistant (almost immune) \\
\hline 9 & Shiranui & 2.6 & $0.0 \%$ & 0.0 & $0.0 \%$ & 0.0 & Highly resistant (almost immune) \\
\hline 15 & PI594767A & 1.3 & $0.0 \%$ & 0.0 & $0.0 \%$ & 0.0 & Highly resistant \\
\hline 39 & Hougyoku & 1.5 & $0.0 \%$ & 0.0 & $0.0 \%$ & 0.0 & Highly resistant \\
\hline 43 & Kinoshita & 1.5 & $00 \%$ & 00 & $00 \%$ & 00 & Highly resistant \\
\hline 22 & GC85037-2-3-5-1 & 1.9 & $0.0 \%$ & 0.0 & $0.0 \%$ & 0.0 & Highly resistant \\
\hline 10 & PI416764 & 1.9 & $0.0 \%$ & 0.0 & $0.0 \%$ & 0.0 & Highly resistant \\
\hline 2 & Tainung 4 & 2.1 & $00 \%$ & 00 & $00 \%$ & 00 & Highly resistant \\
\hline 1 & PI200492 & 2.8 & $0.0 \%$ & 0.0 & $0.0 \%$ & 0.0 & Highly resistant \\
\hline 17 & GC00138-29 & 1.9 & $1.7 \%$ & 0.0 & $0.0 \%$ & 0.0 & Resistant \\
\hline 16 & GC00002-100 & 1.9 & $1.9 \%$ & 0.1 & $0.0 \%$ & 0.0 & Resistant \\
\hline 44 & Abura & 1.2 & $7.1 \%$ & 0.1 & $0.0 \%$ & 0.0 & Resistant \\
\hline 21 & GC84058-21-4 & 2.7 & $13.9 \%$ & 0.1 & $0.0 \%$ & 0.0 & Resistant \\
\hline 48 & BRSMS-Bacri & 1.1 & $12.5 \%$ & 0.8 & $0.0 \%$ & 0.0 & Resistant \\
\hline 18 & GC60020-8-7-7-18 & 1.4 & $132 \%$ & 0.2 & $7.1 \%$ & 0.0 & Resistant \\
\hline 46 & BR01-17996 & 1.0 & $4.3 \%$ & 0.0 & $0.0 \%$ & 0.0 & Resistant \\
\hline 41 & FT2 & 1.3 & $37.8 \%$ & 0.4 & $28.9 \%$ & 0.1 & Resistant \\
\hline 8 & PI459025 & 4.5 & $36.7 \%$ & 0.6 & $0.0 \%$ & 0.3 & Resistant \\
\hline 14 & PI459025A & 1.9 & $40.0 \%$ & 0.6 & $0.0 \%$ & 0.4 & Resistant \\
\hline 7 & PI462312 & 2.0 & $63.3 \%$ & 0.9 & $57.1 \%$ & 0.7 & Resistant \\
\hline 30 & Xiao Jing Huang & 3.5 & $100.0 \%$ & 1.9 & $36.7 \%$ & 1.0 & Slightly resistant \\
\hline 6 & PI417125 & 1.2 & $100.0 \%$ & 2.1 & $67.7 \%$ & 1.6 & Slightly resistant \\
\hline 57 & $\mathrm{BB} 20$ & 4.0 & $96.0 \%$ & 1.4 & $97.6 \%$ & 1.8 & Slightly resistant \\
\hline 4 & PI587886 & 1.5 & $100.0 \%$ & 1.9 & $69.0 \%$ & 1.9 & Slightly resistant \\
\hline 38 & $\mathrm{Da} \mathrm{Li} \mathrm{Zi}$ & 3.3 & $100.0 \%$ & 2.0 & $48.3 \%$ & 2.0 & Slightly resistant \\
\hline 56 & BB19 & 3.6 & $90.0 \%$ & 2.1 & $95.2 \%$ & 2.2 & Susceptible \\
\hline 54 & BB17 & 3.5 & $100.0 \%$ & 1.5 & $100.0 \%$ & 2.3 & Slightly resistant \\
\hline 63 & BB29 & 3.7 & $93.3 \%$ & 1.6 & $81.6 \%$ & 2.3 & Slightly resistant \\
\hline 36 & Lu Pi Dou & 2.0 & $82.4 \%$ & 2.9 & $81.5 \%$ & 2.3 & Susceptible \\
\hline 58 & BB21 & 3.9 & $93.3 \%$ & 2.3 & $91.4 \%$ & 2.4 & Susceptible \\
\hline 13 & Wayne & 2.9 & $100.0 \%$ & 2.5 & $84.2 \%$ & 2.4 & Susceptible \\
\hline 62 & $\mathrm{BB} 28$ & 3.8 & $100.0 \%$ & 3.0 & $84.9 \%$ & 2.4 & Susceptible \\
\hline 20 & GC84051-9-1 & 2.8 & $98.3 \%$ & 2.3 & $90.7 \%$ & 2.5 & Susceptible \\
\hline 61 & BB26 & 4.2 & $100.0 \%$ & 2.4 & $83.6 \%$ & 2.5 & Susceptible \\
\hline 26 & GC87012-10-B-5 & 3.4 & $100.0 \%$ & 3.0 & $84.0 \%$ & 2.5 & Susceptible \\
\hline 59 & BB22 & 4.1 & $100.0 \%$ & 3.5 & $91.3 \%$ & 2.6 & Susceptible \\
\hline 60 & $\mathrm{BB} 25$ & 4.0 & $96.7 \%$ & 2.6 & $91.0 \%$ & 2.6 & Susceptible \\
\hline 40 & Sachiyutaka & 1.7 & $88.2 \%$ & 2.9 & $95.9 \%$ & 2.6 & Susceptible \\
\hline 23 & GC85039-1-2-1-1 & 2.5 & $96.7 \%$ & 2.5 & $93.3 \%$ & 2.7 & Susceptible \\
\hline 47 & BR01-18437 & 1.1 & $100.0 \%$ & 2.4 & $85.6 \%$ & 2.7 & Susceptible \\
\hline 27 & GC87016-11-B-2 & 2.1 & $100.0 \%$ & 3.2 & $90.1 \%$ & 2.7 & Susceptible \\
\hline 24 & GC860049 & 3.1 & $100.0 \%$ & 2.1 & $75.0 \%$ & 2.7 & Susceptible \\
\hline 19 & GC84040-16-1 & 2.5 & $94.8 \%$ & 2.5 & $66.4 \%$ & 2.7 & Slightly resistant \\
\hline 28 & SRE-B-15C & 2.0 & $100.0 \%$ & 2.9 & $91.1 \%$ & 2.8 & Susceptible \\
\hline 50 & Misuzudaizu & 2.9 & $100.0 \%$ & 3.2 & $85.1 \%$ & 2.8 & Susceptible \\
\hline 53 & BRS231 & 2.4 & $100.0 \%$ & 4.2 & $84.9 \%$ & 3.0 & Susceptible \\
\hline 25 & SS86045-23-2 & 3.2 & $100.0 \%$ & 4.4 & $86.4 \%$ & 3.0 & Susceptible \\
\hline 37 & Hei Dou & 2.7 & $98.3 \%$ & 3.9 & $80.8 \%$ & 3.0 & Susceptible \\
\hline 42 & Davis & 2.9 & $100.0 \%$ & 4.0 & $90.2 \%$ & 3.0 & Susceptible \\
\hline 45 & RI75 & 3.8 & $100.0 \%$ & 3.9 & $92.1 \%$ & 3.0 & Susceptible \\
\hline 35 & Himedaizu & 3.9 & $93.3 \%$ & 2.1 & $70.6 \%$ & 3.0 & Susceptible \\
\hline 5 & PI230970 & 1.3 & $100.0 \%$ & 2.2 & $84.8 \%$ & 3.0 & Susceptible \\
\hline 33 & Da Bai Qi & 4.7 & $100.0 \%$ & 2.5 & $89.0 \%$ & 3.0 & Susceptible \\
\hline 32 & Qin Dou & 4.1 & $100.0 \%$ & 3.2 & $91.6 \%$ & 3.0 & Susceptible \\
\hline 55 & BB18 & 4.7 & $100.0 \%$ & 3.2 & $90.7 \%$ & 3.0 & Susceptible \\
\hline 34 & 6611 & 4.5 & $100.0 \%$ & 3.3 & $97.9 \%$ & 3.0 & Susceptible \\
\hline 31 & Niu Mao Huang & 3.2 & $100.0 \%$ & 3.5 & $74.2 \%$ & 3.0 & Susceptible \\
\hline 49 & EMBRAPA48 & 2.2 & $100.0 \%$ & 3.7 & $90.3 \%$ & 3.0 & Susceptible \\
\hline 12 & TK5 & 1.6 & $100.0 \%$ & 4.0 & $78.3 \%$ & 3.0 & Susceptible \\
\hline 52 & BRS184 & 2.4 & $100.0 \%$ & 4.8 & $97.8 \%$ & 3.0 & Susceptible \\
\hline 51 & Moshidou Gong 503 & 2.9 & $100.0 \%$ & 5.1 & $87.0 \%$ & 3.0 & Susceptible \\
\hline
\end{tabular}

${ }^{1}$ The values $0.0 \leq \mathrm{x}<70.0$ and $70.0 \leq \mathrm{x} \leq 100.0$ are respectively classified as indicating resistance (shading) and susceptibility for $\% \mathrm{LU} ;{ }^{2}$ The values $0.0 \leq \mathrm{x}<2.0$ and $2.0 \leq \mathrm{x}$ are respectively classified as indicating resistance (shading) and susceptibility for NoU; ${ }^{3}$ The values $0.0 \leq \mathrm{x}<70.0$ and $70.0 \leq \mathrm{x} \leq 100.0$ are respectively classified as indicating resistance (shading) and susceptibility for $\% \mathrm{OU} ;{ }^{4}$ The values $0.0 \leq \mathrm{x}<2.0$ and 2.0 $\leq \mathrm{x} \leq 3.0$ are respectively classified as indicating resistance (shading) and susceptibility for SL; ${ }^{5}$ Final classification of resistance was determined by the following criteria: "Immune": having no lesions; "Highly resistant": having lesions showing the resistant phenotype in four characters and with no uredinia; "Resistant": having lesions showing resistant phenotype in four characters and with uredinia; "Slightly resistant": having lesions showing resistant phenotype in any of four resistance characters, "Susceptible": having lesions showing susceptible phenotype in all four resistance characters. "Almost immune" means that the genotypes showed imperfect formation of lesions that might have been caused by very strong resistance (shown in Figure. 3). 


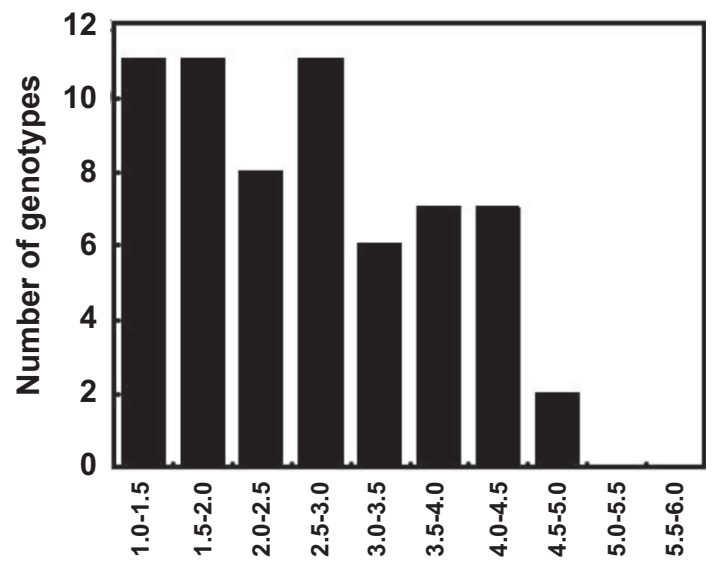

LC

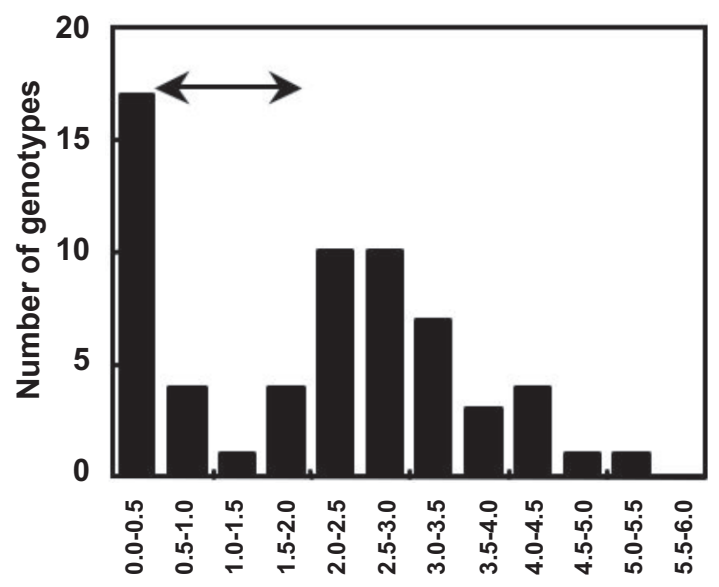

NoU

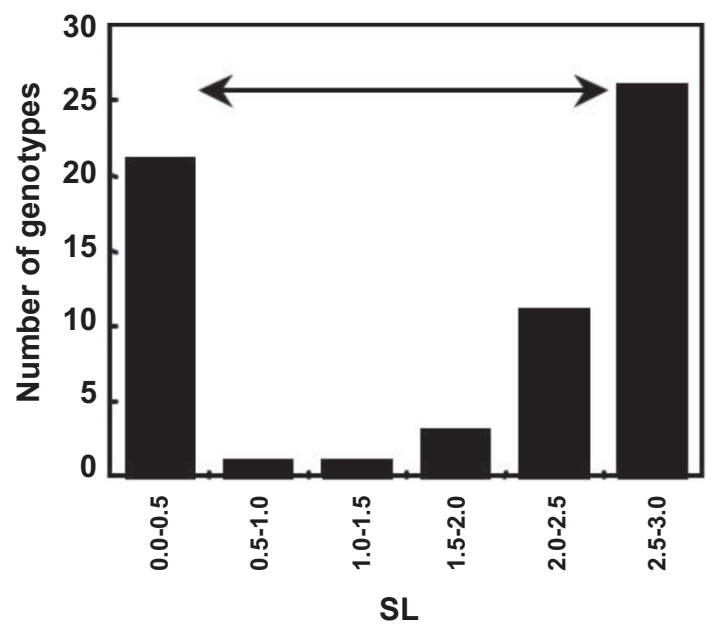

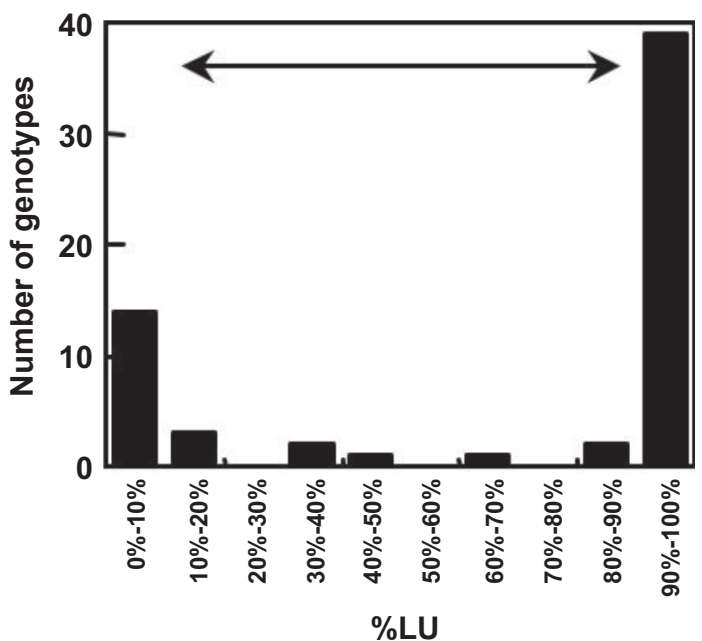

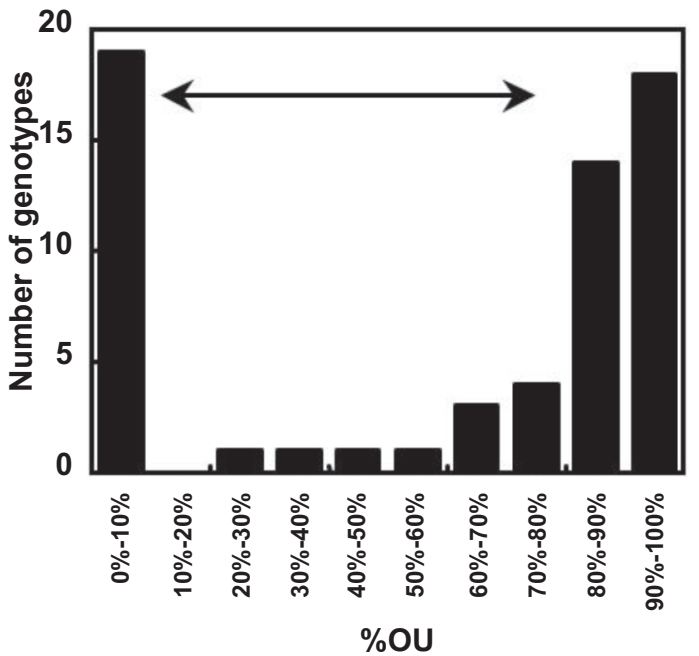

FIGURE 2 - Frequency distribution of the 5 characters for resistance against the Japanese rust population in the 63 genotypes. LC, \%LU, NoU, \%OU, and SL mean lesion color, frequency of lesion having uredinia, number of uredinia per lesion frequency of open uredinia, and sporulation level, respectively. Estimated boundary values between resistant and susceptible phenotypes for each character are shown by arrows. 


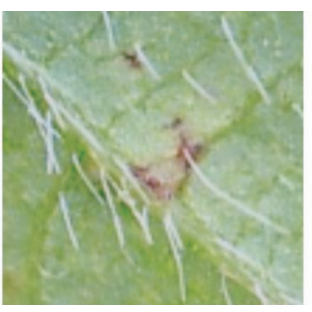

SRE-D-11C

Highly resistant

(Almost immune)

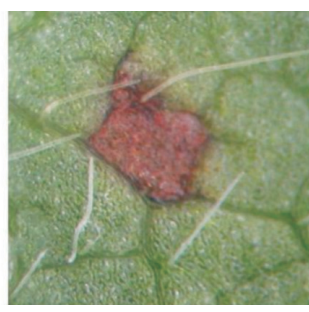

Hougyoku

Highly resistant

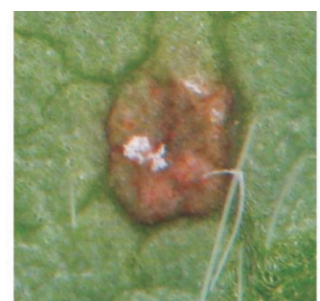

Xiao Jing Huang Slightly resistant

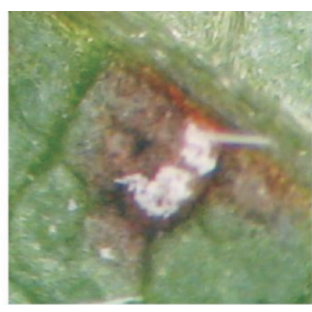

GC84051-9-1

Susceptible

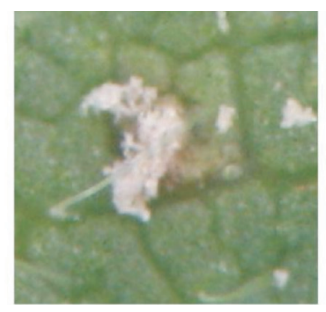

Da Bai Qi

Susceptible

FIGURE 3 - Examples of the different pigmentation and sporulation of lesions observed in the 63 genotypes in response to inoculation with the Japanese rust population.

(0.412 to 0.515$)$ with the other four resistance characters (Table 3). That is, most varieties had the same phenotypesresistance or susceptible - in terms of the four resistance characters, with the exception of LC, and the darkness of LC was not always correlated with the production of uredinia and spores. For example, PI459025 (Rpp4) produced lesions that had a low NoU and SL but a light LC (with score of 4.5, Table 2). On the other hand, PI230970 (Rpp2) and TK5, which had abundant spore production, had dark LC (with scores of 1.3 and 1.6 , respectively).

\section{Classification criteria for resistance to soybean rust}

The frequency distributions of four characters (excluding LC) in the 63 genotypes were bimodal (Figure 2), and two peaks that may have been associated with resistant and susceptible genotypes were observed. The thresholds between resistant and susceptible were determined between these two peaks (Figure 2) for the four resistance characters (excluding LC), as follows. The value of 2.0 for SL was primarily determined as the boundary value for distinguishing resistant $(\mathrm{R})$ and susceptible $(\mathrm{S})$. In this study, SL is considered to be the most important character for soybean rust resistance among the five because the amount of spores produced directly influences multiplication of soybean rust. An SL of less than 2.0 was clearly different from a larger (susceptible) SL. The boundary values between $\mathrm{R}$ and $\mathrm{S}$ for the other three characters were then determined to minimize the number of genotypes showing both $\mathrm{R}$ and $\mathrm{S}$ phenotypes in the four resistance characters. That is, the values $0.0 \leq \mathrm{x}$ $<2.0$ and $2.0 \leq \mathrm{x}$ were respectively classified as resistant and susceptible for NoU. The values $0.0 \leq \mathrm{x}<70.0$ and $70.0 \leq \mathrm{x} \leq 100.0$ were respectively classified as resistant and susceptible for both $\% \mathrm{OU}$ and $\% \mathrm{LU}$.

Finally, all 63 genotypes were classified into five kinds of resistance classification, "Immune", "Highly resistant", "Resistant", "Slightly resistant", and "Susceptible", according to the classification criteria of "Immune" = having no lesions; "Highly resistant" = having lesions showing the resistant phenotype in all four characters and with no uredinia; "Resistant" = having lesions showing the resistant phenotype in all four characters and possessing uredinia; "Slightly resistant" = having lesions that show resistant phenotype in any of four characters; and "Susceptible" $=$ having lesions with susceptible phenotypes in all four resistance characters. These five resistance categories of genotypes were also applied to the other two Brazilian rust populations in order to identify the difference in the virulence among three populations.

\section{Pathogenic differences among the 3 rust populations}

We examined the pathogenic differences among JRP, BRP-1, and BRP-2 in the 13 standard varieties based on the criteria we determined (Figure 4). With BRP-1 infection, a few whitish lesions in 100 dark brown lesions were observed in the genotype, PI416764. With BRP-2 infection, two clearly different types of lesions with similar frequencies were also observed on PI587905. Such mixed lesions were not observed in JRP.

Some pathogenic differences were observed between BRP-1 and BRP-2. Major differences in virulence were observed in PI230970 (Rpp2), PI417125 (Rpp2), PI462312 (Rpp3), and PI416764 (Figure 4). Until 2008, it had not been reported that Brazilian rust populations show virulence against genotypes containing the Rpp 2 gene. In addition, stronger

TABLE 3 - Pearson correlations among the five characters for resistance against the Japanese rust population in the 63 genotypes. All correlations are significant $(P<0.001)$ by t-test. For key to table headings see caption to Table 2

\begin{tabular}{llllll}
\hline \hline & LC & \%LU & NoU & \%OU & SL \\
\hline LC & - & 0.515 & 0.412 & 0.502 & 0.499 \\
$\%$ LU & - & - & 0.873 & 0.951 & 0.944 \\
NoU & - & - & - & 0.868 & 0.926 \\
$\% \mathrm{OU}$ & - & - & - & - & 0.953 \\
$\mathrm{SL}$ & - & - & - & - & - \\
\hline
\end{tabular}




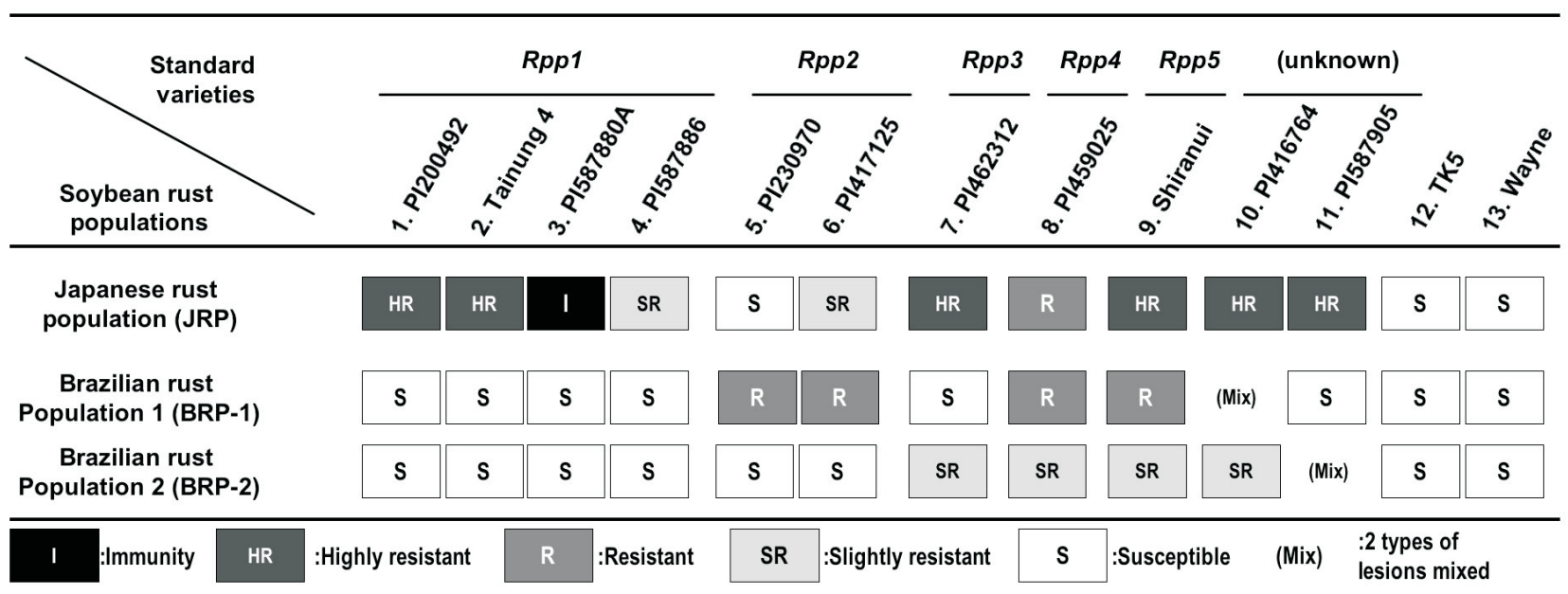

FIGURE 4 - Phenotypes of resistance against Japanese and Brazilian rust populations in 13 standard varieties. 1-9: Varieties having one of known resistance genes, 10 and 11: Varieties having identified their resistance but not identified their genes yet, 12 and 13: Susceptible standard varieties.

virulence of BRP-2 than BRP-1 was observed in PI459025 with the Rpp 4 gene. Thus, the resistance conferred by Rpp 4 from PI459025 against Brazilian populations might have started to break down. Clear differences in virulence between the Japanese and the two Brazilian populations were observed in all four varieties that have the Rppl gene: PI200492, Tainung 4, PI587880A, and PI58788. All the differences in these varieties involved the Brazilian populations causing stronger disease than the Japanese one.

\section{DISCUSSION}

\section{Various types of lesions obtained from JRP infection}

We considered that following factors were likely to have been associated with various types of lesions observed in JRP infection. First, not only major resistance genes but also minor resistance genes may have influenced these resistance characters. A continuous degree of resistance has previously been observed among soybean lines that have identical compositions of the major resistance genes but have different genetic backgrounds (Nogueira et al., 2008; Yamanaka et al., 2008). In this study, PI417125, which has the major resistance gene, Rpp2, did not show as clearly resistant but were seen to be slightly resistant (Table 2). This is also an example of the major resistance genes showing their resistance quantitatively or soybean varieties having quantitative trait loci for resistance characters except for major genes. Second, the mixture of races in JRP might have produced continuous variation in the average values of the characters in the 30 lesions sampled per genotype. Mixed types of lesions, which can be clearly distinguished from each other, were not observed in JRP infection. However, it is difficult to differentiate types of pathogenic races without clear differences in their LCs or SLs. Thus, the average values of the resistance characters could have been derived from different pathogenic races. Consequently, the use of both lines that are isogenic for each major resistance gene and single-lesion isolates taken from rust populations will be necessary to determine the boundaries between resistant and susceptible types more exactly.

\section{Classification criteria for resistance to soybean rust}

The resistance genes Rpp2 and Rpp 4 contribute genetically to the darkness of LC against BRP-1 under greenhouse conditions (Yamanaka et al., 2008). PI459025 (Rpp4) had an LC score that differed with the growth environment, namely 4.5 in this study and 1.2 under greenhouse conditions (data not shown). This suggests that LC is easily influenced by environmental factors. We consider spore production to be more important than LC in the identification of resistance against soybean rust. LC showed a low correlation with the other four resistance characters, which appear to be more important for selection in the breeding program (Table 3). This, combined with apparent variation with environmental factors mentioned above and the fact that it shows not bimodal but continuous distribution (Figure 2), makes it unlikely to be a suitable criterion for resistance classification of genotypes. However, a clear difference in LC is considered to be useful for detecting mixed lesions derived from different pathogenic races.

The difference in the virulence among three rust populations was successfully revealed by the classification criteria for resistance which we developed. Therefore, it can be used for identifying the genes/varieties effective for the other rust populations. However, the evaluation methodology and the classification criteria mentioned in this paper are not universal in all phases of the breeding program. For example, DNA markers or visual classification of RB/TAN may be useful when we select the lines from the population where the major resistance genes segregate, 
and Severity check may also be useful for introducing the minor genes and for evaluating effectiveness of fungicide application (Godoy et al., 2009). In addition, we observed high correlation among 4 characters related to resistance. This observation may enable us to simplify the process of evaluation. The criteria to decide resistance against soybean rust were determined by large number of phenotypes: four characters in 63 genotypes. However, phenotypic data of genotypes shown in this study are based on a one-time experiment, and thus we have to treat the data carefully by considering that.

\section{Pathogenic differences among the 3 rust populations}

The two Brazilian rust populations previously shown to have similar virulence in a different set of differential varieties in 2005 (Kato \& Yorinori, 2008), showed some difference in their virulence in this study. Therefore, the differences observed here are likely to have resulted from a change in virulence, large changes in the race population, or both, which occurred from 2005 to 2008 in the two greenhouses. Phenotypes resistant to BRP-1 or BRP-2 were observed in varieties with the genes Rpp2, Rpp3, Rpp4, and Rpp5 (entries 5 to 9) and in PI416764, but only two of these varieties, PI459025 (Rpp4) and cv. Shiranui (Rpp5), were resistant to both Brazilian populations (Figure 4). In other words, only two of the five major genes can be expected to be useful in resistance to Brazilian soybean rust. In addition, Brazilian populations caused more virulent reaction than Japanese populations in 13 standard varieties. With the infections of two Brazilian populations, two clearly different types of lesions were observed in the genotypes, PI416764 and PI587905, respectively for BRP-1 and BRP2 , in 13 standard varieties. However, such mixed lesions were not observed in JRP infection using 63 genotypes. This fact indicated that Brazilian rust populations may have not only higher but also more diverse virulence than the Japanese one. The most significant difference between the Japanese and Brazilian populations was observed in the 4 genotypes having Rppl gene in this study. Pham et al. (2009) detected a susceptible reaction of Rppl (PI200492) in the Brazilian isolate, but immunity and resistant reactions in the Indian and Louisiana isolates, respectively. $\mathrm{Li}$ (2009) also detected high resistance in PI200492 against 3 isolates from Mississippi. Thus, the resistant allele of Rppl from PI200492 can be useful in some regions of Asia and the USA but not in Brazil.

Our results suggested that the resistant varieties or resistance genes useful in Brazil were limited. They also suggested that a breakdown of major resistance genes or large changes in race populations, as observed in the case of the Rpp 2 gene (from PI230970 and PI417125), are occurring. Therefore, a resistant cultivar that is universally effective against soybean rust should be developed by pyramiding many major resistance genes and by introducing horizontal resistance.

\section{ACKNOWLEDGEMENTS}

We thank Tomomi Mori and Akiko Takahashi of the Japan International Research Center for Agricultural Sciences - JIRCAS for their technical assistance. We also thank Drs. José Tadashi Yorinori (Tadashi Agro), and Hajime Akamatsu (JIRCAS) for their technical advice and encouragement. We are grateful to the Asian Vegetable Research and Development Center - AVRDC, the Soybean Research Center, the Jilin Academy of Agricultural Sciences - JAAS, Chiba University, Brazilian Agricultural Research Corporation - EMBRAPA, and National Institute of Crop Science - NICS for providing seeds of plant materials. This study was conducted under the JIRCAS research project, "Identification of Stable Resistance to Soybean Rust for South America".

\section{REFFERENCES}

Arias CAA, Toledo JFF, Almeida LA, Pipolo AE, Carneiro GES, Abdelnoor RV, Rachid BF, and Ribeiro AS (2008) Asian rust in Brazil: Varietal resistance. In: Kudo H, Suenaga K, Soares RM, Toledo A (Eds.) JIRCAS Working Report No. 58. Tsukuba Japan. JIRCAS. pp. 29-30.

Asian Vegetable Research and Development Center (1989) Progress Report 1989. Shanhua, Taiwan, AVRDC Publication.

Asian Vegetable Research and Development Center (1992) Progress Report 1992. Shanhua, Taiwan, AVRDC Publication.

Bonde MR, Nester SE, Austin CN Stone CL, Frederick RD, Hartman GL, Miles MR (2006) Evaluation of virulence of Phakopsora pachyrhizi and P. meibomiae isolates. Plant Disease 90:708-716.

Bromfield KR (1984) Soybean Rust - Monograph No. 11. Saint Paul MN. APS Press.

Bromfield KR, Hartwig EE (1980) Resistance to soybean rust and mode of inheritance. Crop Science 20:254-255.

Fehr WR, Caviness CE, Burnood DT, Pennington JS (1971) Stage of development descriptions for soybeans, Glycine $\max (\mathrm{L}$.) Merril. Crop Science 11:929-931.

Garcia A, Calvo ÉS, Kiihl RA de S, Harada A, Hiromoto DM, Vieira LGE (2008) Molecular mapping of soybean rust (Phakopsora pachyrhizi) resistance genes: discovery of a novel locus and alleles. Theoretical and Applied Genetics 117:545-553.

Godoy CV, Flausino, Santos LCM, Del Ponte EM (2009). Eficiência do controle da ferrugem asiática da soja em função do momento de aplicação sob condições de epidemia em Londrina, PR. Tropical Plant Pathology 34:56-61.

Hartwig EE (1986) Identification of a 4th major gene conferring resistance to soybean rust. Crop Science 26:1135-113.

Hartwig EE, Bromfield KR (1983) Relationships among 3 genes conferring specific resistance to rust in soybeans. Crop Science 23:237-239.

Hennings VP (1903) A few new Japanese Uredinaceae. Hedwigia 42:107-108 
N. Yamanaka et al.

Ivancovich A (2005) Soybean rust in Argentina. Plant Disease 89:667-668.

Kato M, Yorinori JT (2008) A study on a race composition of Phakopsora pachyrhizi in Brazil: a difficulty of race identification. In: Kudo H, Suenaga K, Soares RM, Toledo A (Eds.) JIRCAS Working Report No. 58. Tsukuba Japan. JIRCAS. pp. 94-98.

Laperuta LDC, Arias CAA, Ribeiro AS, Rachid BF, Pierozzi PHB, Toledo JFF, Pípolo AE, Carneiro GES (2008) New genes conferring resistance to Asian soybean rust: allelic testing for the Rpp2 and Rpp4 loci. Pesquisa Agropecuária Brasileira 43:1741-1747.

Li S (2009) Reaction of soybean rust-resistant lines identified in Paraguay to Mississippi isolates of Phakopsora pachyrhizi. Crop Science 49:887-894.

Miles MR, Frederick RD, Hartman GL (2006) Evaluation of soybean germplasm for resistance to Phakopsora pachyrhizi. Plant Health Progress doi 10.1094/PHP-2006-0104-01-RS.

Monteros MJ, Missaoui AM, Phillips DV, Walker DR, Boerma HR (2006) Mapping and confirmation of the 'Hyuuga' red-brown lesion resistance gene for Asian soybean rust. Crop Science 47:829-834.

Navarro JC, Nakasato R, Utiamada CM, Yorinori JT (2004) First report of "Asian" soybean rust in Bolivia. In: Moscardi F et al. (Eds.) Abstracts of contributed papers and posters / VII World Soybean Research Conference, IV International Soybean Processing and Utilization Conference, III Congresso Brasileiro de Soja. Londrina PR. Embrapa Soja. pp. 85-86.

Nogueira LM, Passionotto ALL, Silva DCG, Santos JVM, Arias CAA, Abdelnoor RV \& Yamanaka N (2008) Os genes de resistência à ferrugem asiática da soja, Rpp2 e Rpp4, apresentam efeitos nãoaditivos quando acumulados em uma variedade. Tropical Plant Pathology 33 (Supl.):204.

Oliveira ACB, Godoy CV and Martins MC (2005) Avaliação da tolerância de cultivares de soja à ferrugem asiática no Oeste da Bahia. Fitopatologia Brasileira 30:658-662.

Oloka HK, Tukamuhabwa P, Sengooba T, Shanmugasundram S (2008) Reaction of Exotic Soybean Germplasm to Phakopsora pachyrhizi in Uganda. Plant Disease 92:1493-1496.

Pham TA, Miles MR, Frederick RD, Hill CB, Hartman GL (2009) Differential responses of resistant soybean entries to isolates of Phakopsora pachyrhizi. Plant Disease 93:224-228.

Pierozzi PHB, Ribeiro AS, Moreira JUV, Laperuta LDC, Rachid BF, Lima WF, Arias CAA, Oliveira MF, and Toledo JFF (2008) New soybean (Glycine max Fabales, Fabaceae) sources of qualitative genetic resistance to Asian soybean rust caused by Phakopsora pachyrhizi (Uredinales, Phakopsoraceae). Genetics and Molecular Biology 31:505-511.

Ray JD, Morel W, Smith JR, Frederick RD, Miles MR (2009) Genetics and mapping of adult plant rust resistance in soybean PI 587886 and
PI 587880A. Theoretical and Applied Genetics 119:271-280.

Ribeiro AS, Toledo JFF, Arias CAA, Godoy, CV, Soares RM, Moreira JUV, Pierozzi PHB, Vidigal MCG, Oliveira MF (2008) Genetic control of soybean (Glycine max) yield in the absence and presence of the Asian rust fungus (Phakopsora pachyrhizi). Genetics and Molecular Biology 31:98-105.

Rossi RL (2003) First report of Phakopsora pachyrhizi, the causal organism of soybean rust in the province of Misiones, Argentina. Plant Disease 87:102.

Silva DCG, Yamanaka N, Brogin RL, Arias CAA, Nepomuceno AL, Di Mauro A, Pereira S, Nogueira LM, Passianotto ALL, Abdelnoor RV (2008) Molecular mapping of two loci that confer resistance to Asian rust in soybean. Theoretical and Applied Genetics 117:57-63

Yamanaka N, Ninomiya S, Hoshi M, Tsubokura Y, Yano M, Nagamura Y, Sasaki T, and Harada K (2001) An informative linkage map of soybean reveals QTLs for flowering time, leaflet morphology and regions of segregation distortion. DNA Research 8:61-72.

Yamanaka N, Sato H, Yang Z, Xu DH, Catelli LL, Arias CAA, Abdelnoor RV, Nepomuceno AL (2007a) Genetic relationship of Japanese, Chinese and Brazilian soybean gene pools revealed by SSR markers. Genetics and Molecular Biology 30:85-88.

Yamanaka N, Silva DCG, Gilli JR, Fuentes FH, Yang Z, Polizel A, Sato H, Watanabe S, Ban T, Homma Y, Harada K, Brogin RL, Nepomuceno AL, Abdelnoor RV (2007b) Application of DNA markers for identifying genes for resistance to soybean diseases in South America and for evaluating genetic relationships among soybean gene pools. In: Suenaga K, Kudo H, Oshio S (Eds.) JIRCAS Working Report No. 51. Tsukuba Japan. JIRCAS. pp. 47-54.

Yamanaka N, Silva DCG, Passianotto ALL, Nogueira LM, Polizel AM, Pereira SS, Santos JVM, Brogin RL, Arias CAA, HoffmannCampo CB, Nepomuceno AL, Abdelnoor RV (2008) Identification of DNA markers and characterization of the genes for resistance against Asian soybean rust. In: Kudo H, Suenaga K, Soares RM, Toledo A (Eds.) JIRCAS Working Report No. 58. Tsukuba Japan. JIRCAS. pp. 99-107.

Yamaoka Y, Fujiwara Y, Kakishima M. Katsuya K, Yamada K, Hagiwara H (2002) Pathogenic races of Phakopsora pachyrhizi on soybean and wild host plants collected in Japan. Journal of General Plant Pathology 68:52-56.

Yorinori JT (2008) Soybean germplasms with resistance and tolerance to Asian rust and screening method. In: Kudo H, Suenaga K, Soares RM, Toledo A (Eds.) JIRCAS Working Report No. 58. Tsukuba Japan. JIRCAS. pp. 70-87.

Yorinori JT, Paiva WM, Frederick RD, Costamilan LM, Bertagnoli PF, Hartman GL, Godoy CV, Nunes JJ (2005) Epidemics of soybean rust (Phakopsora pachyrhizi) in Brazil and Paraguay from 2001 to 2003. Plant Disease 89:675-677.

\section{Este artigo sofreu al terações por solicitação do editor em ago/2010 conforme ERRATA publicada no Volume 35 Número 4 do periódico. (http://www.scielo.br/pdf/tpp/v35n4/v35n4a11.pdf)}

